\title{
FROM SYPHILITIC TO SUFFRAGIST: THE WOMAN'S FOURNAL AND THE NEGOTIATION OF WALT WHITMAN'S CELEBRITY
}

\author{
TODD H. RicHARDSON
}

IN 1888, WALT Whitman proclaimed to Horace Traubel that "Leaves of Grass is essentially a woman's book ... it speaks out the necessities, its cry is the cry of the right and wrong of the woman sex-of the woman first of all, of the facts of creation first of all-of the feminine: speaks out loud: warns, encourages, persuades, points the way." Up to the present day, scholars have debated whether or not Whitman was progressive both in his conceptualization of this aim and in his carrying it out. Joyce Warren, for example, has given a persuasive argument against Whitman's ability to produce sympathetic representations of women. Drawing upon D. H. Lawrence's famous epigram that Whitman saw women as nothing more than "Muscles and Wombs," she writes, "[A]lthough he was unusual in his day for recognizing woman's physical nature, he never regarded her as a doer in the way that he did man; he never saw woman as a person independent of her relation to man." ${ }^{2}$ Sherry Ceniza has given an equally persuasive argument favoring Whitman's depictions of women. She argues against the notion that Whitman "saw women only as agents of reproduction, as wombs," noting that "Whitman wanted to expand the meaning of the term 'motherhood,' to go beyond biology. . . . He wanted the body to be a freeing force in a person's life, not constricting." 3

A consideration of contemporary women's rights activists, however, reveals that representations of Whitman's iconic status concerned other factors than the extent to which the Good Grey Poet presented a compelling case for women's physical and intellectual strength; furthermore, it reveals that those representations underwent a process of negotiation and transformation over a period of several decades. Using over twenty previously unknown references to Whitman in the Woman's Fournal (1870-1917), America's most prominent and long-lived suffrage periodical, I will demonstrate that the influential suffrage community supported by this periodical first configured Whitman as a recalcitrant sensualist and later reconfigured him as an inspired suffragist whose appropriated poetry encouraged women to carry on the suffrage fight. ${ }^{4}$ 
Headquartered in Boston, the periodical was the unofficial organ of the American Woman Suffrage Association (AWSA) and, by 1910, the official organ of the National American Woman Suffrage Association (NAWSA). Each week, the fournal announced its devotion "to the interests of Woman, to her educational, industrial, legal and political Equality, and especially to her right to suffrage." Among the fournal's editors and contributors were Lucy Stone, Henry Blackwell, Alice Stone Blackwell, Julia Ward Howe, and Thomas Wentworth Higginson. Compared to the New York-based National Woman Suffrage Association (NWSA), headed by Elizabeth Cady Stanton and Susan B. Anthony, the AWSA, operating among the genteel Bostonians, was conservative. ${ }^{5}$

This basic difference in temperament between the suffrage communities ultimately led to the fournal's effort to distance itself from Whitman. Among the specific points of contention between the two groups, Free Love activism was one of the more prominent. As the name suggests, Free Love activists demanded greater personal control over marriage and sexual relationships. Although some activists promoted multiple sexual partners, premarital sex, and the like, more often than not the movement simply called for the relaxation of divorce law-now a concern of obvious import to the women's rights movement. To a degree, the NWSA embraced the radical reform, but the staid fournal community refused to entertain it, believing that such would only give detractors the opportunity to characterize suffragists as licentious misfits. As David Reynolds has demonstrated, Whitman was deeply associated in the popular imagination with Free Love: "Emerson connected him with the free-love movement, as did James Harlan, Whitman's superior in the Interior Department who in 1865 fired him, reportedly, in the belief that 'he was a free lover, deserved punishment, \&c"' (222). ${ }^{6}$ As a result, the fournal community in its early years wanted to steer clear of him.

The specific incident which precipitated the fournal's active stance against Free Love and, by association, Whitman, was the sensational Henry Ward Beecher divorce trial. The trouble began with the infamous Victoria Woodhull and her sister Tennessee Claflin, notorious spiritualists, quack healers, suffrage reformers, and advocates of Free Love. When Beecher, the beloved and enormously popular evangelical preacher, refused Woodhull's request in 1872 to publicly countenance the sisters' openly freewheeling lifestyle, the sisters exposed his extramarital affair with Elizabeth Tilton, the wife of Theodore Tilton, editor of the prominent periodical the Independent. The resulting trial became the scandal of the decade, occupying public attention for months. The mess had profound implications for the suffrage community because Elizabeth Cady Stanton and others of the NWSA had publicly admired 
Woodhull's fiery suffrage speeches and her bold announcement in 1870 to run for President of the United States. ${ }^{7}$

Naturally, the comparatively conservative fournal community did everything it could to distance itself from this outrage originating in the Free Love corners of the suffrage movement. In September 1874, as the Beecher scandal was in full swing, Henry Blackwell wrote in the Fournal that "Woman Suffrage has no more connection to Free Love than has Manhood Suffrage. One might as well assert that theft and murder are the fruits of the Suffrage movement, as to say that Free Love is the fruit of the Suffrage movement." In August 1876, one M. G. Charlton, certainly implicating Woodhull and possibly Stanton, opined that " $[\mathrm{w}] \mathrm{e}$ know of no leader in the Woman movement who is an advocate of free-love. There are some 'wolves in sheep's clothing,' who seek to identify the two causes, but the great mass of the advocates of Woman Suffrage not only refuse to recognize but utterly denounce them." The "real" suffragists, then, are staid upholders of "purity," a foundational virtue of true womanhood. Twenty years later, Blackwell was still fighting the popular association of suffrage with Free Love based on the events of the early 1870s. To a preacher's claim that "nearly all the leaders of the Woman Suffrage movement twenty years ago were infidels and free-lovers," Blackwell retorted that "the most conclusive ... refutation is to name some of [suffrage's] most prominent advocates." The list of names included over a dozen icons of New England culture who also evidently believed that love was very expensive, such as Margaret Fuller, Louisa May Alcott, Lydia Maria Child, Thomas Wentworth Higginson, and Ralph Waldo Emerson, a figure the fournal had appropriated for years as a suffrage advocate even without substantial evidence of his support. ${ }^{10}$

In the mid-1870s, not coincidentally, the first short pieces on Whitman began to appear in the Woman's fournal. In Whitman the fournal community found a convenient foil who helped establish their distance from the Free Love crowd. In August 1875, when the Beecher scandal was in full bloom, the fournal printed the following short unsigned "Notes and News" item:

It is a singular commentary on the one especial claim made for the eccentric Walt Whitman by his admirers - that, namely, of being "the poet of health and strength" - that one of his most extravagant eulogists in the Springfield Republican says of him that "Though he be taken at first sight for 75 or 80 , he is in fact not yet $57 . " 11$

Obviously, the piece makes it clear that the fournal did not count itself among Whitman's "admirers" and was confident that its community of readers believed the same. Further, the claim that Whitman had aged prematurely presents a number of interpretive possibilities, including, 
most broadly, dissipation and sexual profligacy, and probably syphilis. According to David Reynolds, Whitman had a widespread and decades long reputation as a "womanizer" (197). Concerning syphilis, Higginson, inveterate Whitman hater, implied very strongly (in an obituary notice no less) that the Good Grey Poet suffered from the disease as late as 1892, as was evident from "paralysis, insanity, and premature old age" as well as "premature senility."

Another short article, published in December 1875 when the Beecher scandal was still a media sensation, engages the same line of attack with a more overt implication of dissipation. It reads as follows:

'Joaqui[n]' Miller (Cincinnatus Hiner Miller) writes of Walt Whitman as 'A plain brave old man.' Mr. Whitman is fifty-eight, a time of life when an average man of good constitution and habits should be in his prime. If Mr. Whitman is not, it looks as if his worship of the body had not profited him. ${ }^{13}$

Characterizing Whitman's "worship of the body" as ultimately leading to physical degeneracy (most likely code for syphilis once again), the suffrage community could maintain its contrasting "superior" values concerning gender roles, sexual morality, and marital relationships even while it promoted greater equality for women.

Certainly the most important anti-Whitman piece of this time period is Thomas Wentworth Higginson's "Unmanly Manhood," which was printed in February 1882. ${ }^{14}$ This is the only piece from the fournal concerning Whitman which has been known, and it has received extensive treatment from such scholars as Ed Folsom, Scott Giantvalley, Kenneth Price, and Robert Nelson. It tends to be read as a self-righteous, idiosyncratic outburst (which, doubtless, it was to some extent) in context of a host of other Whitman-bashing essays Higginson penned over the years for such periodicals as the Nation and Harper's Bazar. As far as I can ascertain, however, it has never been interpreted as another manifestation of the fournal's sustained campaign to define itself against such disreputable elements of the suffrage movement as the Free Love crowd. ${ }^{15}$ In the article, Higginson faulted would-be progressive women-women not unlike Woodhull and Stanton-for allowing "the poems of Wilde and Whitman" into their "boudoirs" and for misconstruing such poetry as "manly." (Oscar Wilde was just then on his tour of America.) Higginson asked, "Is it manly to fling before the eyes of women page upon page which no man would read aloud in the presence of women?" For radical expositors of Free Love who were moving beyond Higginson's chivalric construction of masculinity, of course, such would not be an issue. Further problematizing Whitman's sensuality, Higginson sounded a theme already familiar to readers of the fournal: he questioned Whitman's courage and physical strength and health. He continued: 
But there is another test of manhood; it lies in action. I am one of many to whom Whitman's "Drum-Taps" have always sounded as hollow as the instrument they counterfeit, simply because the author with all his fine physique and his freedom from home-ties, never personally followed the drum, but only heard it from the comparatively remote distance of the hospital. There was a time when the recruiting officers wanted men; their test was final ... he who did not meet it, no matter for what good reasons, had best cease boasting about his eminent manhood.

Higginson's characterization of Whitman's physique as "fine" is certainly ironic and suggests a charge of hypocrisy which goes beyond a refusal to fight in the war-if Whitman lived up to the ideals he presented in his own poetry, he would have ensured that his own body remained a quality specimen of manhood through virtuous behavior; since he had not, he ought to have the decency to allow others (like Higginson) speak for his gender. Only one month after Higginson penned this article, Leaves of Grass was banned in Boston, and many critics, past and present, believe that Higginson played a significant role. ${ }^{16}$ A number of individuals in Boston's Free Love community, including Ezra Hervey Heywood, who had published a couple of Whitman's poems in his periodical, came to Whitman's defense, a development that would not have surprised the conservative suffragists in the least (Reynolds, 542).

Also evident in Higginson's condemnation of Whitman is a classbased distaste for his celebration of working class masculinity - particularly in what he deemed to be Whitman's uncouth behavior towards women. Such classism is evident elsewhere in the fournal, particularly in its 1886 notice of Sidney Lanier's The English Novel and the Principle of Its Development, which most certainly could have been written by Higginson as well. ${ }^{17}$ The fournal introduced an extensive quotation from the southern poet and scholar as follows: "The opposition to woman suffrage grows mainly out of a savage ideal of 'manfulness' and of 'democracy.' Its most consistent and repulsive expression is found in the so-called poetry of Whitman. Sidney Lanier, with true poetic insight, thus punctures the bubble." The passage from Lanier included the observation that "Everywhere through Whitman's poetry the 'rude muscle,' the brawn, ... . the sinew of the Western backwoodsman, are apotheosized. ... [A] republic depends upon the self-control of each member; you cannot make a republic out of muscles and prairies and Rocky Mountains: republics are made of the spirit."18 Unlike the earlier critiques of Whitman's rough manly sensuality, which had been associated more clearly with the radical Free Love movement, here it is associated with the class-based fear that working-class conceptions of masculinity would come to define American democracy, and such "savagery" would leave no place for woman suffrage. Unsurprisingly, Higginson completely agreed with Lanier's assessment in his enthusi- 
astic review of the book which appeared in Harper's Bazar nine months later. ${ }^{19}$ Whether the fournal community criticized Whitman for his promotion of Free Love or working class masculinity, it could define itself in contrast as an upholder and promoter of conventional middleclass respectability in hopes that the conventional middle class would come to embrace suffrage reform.

With such long-standing and even virulent antipathy to the Good Grey Poet, it would seem hard to imagine that the fournal not only dropped its resistance, but welcomed his manly embrace. Such factors as Whitman's improving reputation in the nation at large, the unification of the American Woman Suffrage Association and the National Woman Suffrage Association in 1890, and the general relaxation of sexual morality with the rise of the "New Woman" all contributed. But the most immediate cause was the 1889 publication of Elizabeth Porter Gould's edition of Whitman's poetry entitled Gems from Walt Whitman. ${ }^{20}$ The edition has received a good amount of critical attention in recent years for its capacity to make Whitman more palatable to a larger audience - an audience, I would argue, which most certainly included the fournal's reading community. Ed Folsom demonstrates that Whitman cooperated with Gould's effort, even though she excised the most controversial poems, because he was eager to secure more readers: "Maybe the mined-out and slimmed-down version of Leaves could do what the complete book never could: that is, could sell, could make its author famous, could make his country finally begin to absorb him as affectionately as he had absorbed it."21 Edward Whitley writes, "By and large, the poems in Gems from Walt Whitman present Whitman as a New England transcendentalist concerned with matters cosmic and mystical rather than a New York rowdy who writes about the body and sex." 22

Like the larger reading public, the suffragists were finally able to "absorb" Whitman because the new volume constructed a completely new conception of him free of the cultural markers associated with the working class and the Free Love movement. It also helped that Gould herself was a prominent New England suffragist and club woman who contributed regularly to the Woman's fournal. And it didn't hurt either that she was related to the Emersons and the Peabodys - figures beloved in the New England suffrage community. ${ }^{23}$

As significant, I would argue, is the fact that the selections tended toward passages which demonstrated, for Gould, Whitman's advanced appreciation for women's strength. Included is Whitman's most recognizable statement regarding woman's value from "Song of Myself": 
I am the poet of the woman same as the man,

And I say it is as great to be a woman as to be a man,

And I say there is nothing greater than the mother of men. (44)

For women readers conditioned to invisibility in men's texts, this direct reference to their deep poetic value would have been electrifying, D. H. Lawrence's later critique notwithstanding. Gould also selected generously from "Pioneers! O Pioneers!" including, significantly, the following stanza:

O you daughters of the West!

$\mathrm{O}$ you younger and elder daughters! O you mothers and you wives!

Never must you be divided, in our ranks you move united, Pioneers! O Pioneers! (30)

For the suffragists, the pioneer was an apt and timely metaphor for themselves and their effort to re-create civilization in ways never before conceived, and it was used quite often in their community. Speaking specifically of Whitman's usage, pioneer women were not subject to the same confining notions of "true womanhood" which held sway in eastern states, and western states and territories were the first to give women the vote. Additionally, Whitman's exhortation that pioneer women "Never . . . be divided" echoed with the most profound hopes of the suffragists for all women. Recognizing in Whitman a spirit kindred to such pioneering women, Gould dedicated her volume to Whitman, in part, as follows:

O poet bold and free as is the land that gave thee birth!

A pioneer, "immense in passion, pulse, and power,"

Who, boldly entering nature's shrine and seeing there no wrong,

Made willing haste to free the world cant-held so long.

Clad in the robe of truth by strong conviction wrought,

Thou wast as true to self as nature. (5)

As the passage implies, the natural space that Whitman helped transform was the human body - more specifically, the woman's body - as the line, "boldly entering nature's shrine and seeing there no wrong," would suggest. Hardly an oppressive colonizer of this "new" space, Whitman played a pivotal role in its emancipation from worn-out and extrinsic conceptions of "wrong," which had kept it unjustly defined and confined. As I will discuss shortly, the image of Whitman as pioneer came to resonate deeply with the suffrage community.

Finally, Gould's collection concluded with a substantial essay entitled "Walt Whitman among the Soldiers" which detailed Whitman's ministrations to the sick and dying soldiers in Washington, D.C., during 
the Civil War. Essentially, Gould reconfigured Whitman as a deeply Christian man with her great emphasis on his prayer for the soldiers and his reading of Scripture. The essay, then, served as a powerful and direct refutation of Higginson's charge that Whitman was a coward for working in the hospitals instead of joining the active military campaigns. Even further, Gould, through her praise of Whitman, was able to champion the difficult, brave, and heart-wrenching work of the countless women who also nursed soldiers during the Civil War. In the essay's opening, she quotes Familiar Studies of Men and Books by Robert Louis Stevenson, who wrote that Whitman's "memoranda of this period are almost bewildering to read.... More than one woman... immediately claimed the writer for a fellow-woman" (53).

With Gould's powerful endorsement, then, the negative association of Whitman with the most threatening elements of the radical fringe had come to an end. Henry Blackwell gave a short but wholly appreciative notice of the edition in the fournal: "These brief and telling passages, published without note or comment, from Whitman's poems, carry with them in their force and beauty their own encomium." ${ }^{24}$ Indicating how significant the little edition became in the suffrage community, Blackwell gave it prominent notice sixteen years later in his highly laudatory obituary for Gould: "She was among the first to recognize the great original power of Walt Whitman, and made a collection of his deepest and most beautiful thoughts under the title of 'Gems from Walt Whitman" (Blackwell 1906, 123). That he would characterize Gould as "among the first" is telling, however inaccurate. As Sherry Ceniza has demonstrated, many individual suffragists such as Mary Chilton and Paulina Wright Davis had embraced Whitman decades earlier. Either Blackwell was reinforcing the conception that such women were categorically "wolves in sheep's clothing," as Charlton had termed them, or that their efforts to introduce Whitman to a wider audience of suffragists had, in contrast, completely failed. Whichever the case, Gould's heretofore unrecognized effort to introduce Whitman to the suffragist community was enormously successful.

In the decade following the publication of Gould's volume, the fournal gave other indications that its countenance upon the Good Grey Poet was softening. In June of 1890, it gave a favorable notice of artist Dora Wheeler. Whitman scholars have known that Wheeler was the only woman to have painted Whitman from life, and the fournal praised the artist for, among other accomplishments, painting an "excellent likeness" of Whitman. ${ }^{25}$ The periodical also praised the Manhattan Liberal Club in March 1895 for its inclusion of women in its leadership and for its "diffusion of progressive thought." Recommended lectures included "Walt Whitman" by New York Unitarian minister Merle St. C. 
Wright. ${ }^{26}$ That publishers were convinced the fournal community had at last become a good market for books concerning Whitman is evinced by at least one advertisement that appeared in these years-Houghton Mifflin's release of John Burroughs's Whitman: A Study. ${ }^{27}$ And one more review of Whitman's work appeared in 1898. The book, the Complete Prose Works by Walter Whitman, was noticed, in part, as follows:

This is a remarkable compilation of all that Walt. Whitman is known to have written in prose....The whole gives a most readable view of his life in a fragmentary or discursive form. They give, also, vivid pictures of the country, from his native Long Island to the Pacific Ocean; of society, past, present, and to come; of his boyhood, youth, manhood, and old age; of the Civil War, as seen in camp and hospital; of his own unique and sympathetic personality. ${ }^{28}$

A few years earlier, Whitman's point of view on anything, let alone his "sympathetic personality," would have been of absolutely no interest to the fournal community.

Even Higginson showed signs of coming around one year later. Although he had left the fournal in 1884, he remained immersed in the suffrage movement as well as broader New England reform culture. The fournal gave a brief notice of Higginson's book Contemporaries, calling it a "delightful volume" for which Higginson has drawn upon "his store of recollections of the lights of a generation ago." Whitman is then mentioned in the same breath as Emerson, Theodore Parker, Sidney Lanier, Sophia Hawthorne, and such radical abolitionists as John Greenleaf Whittier, William Lloyd Garrison, Lydia Maria Child, Charles Sumner, and Wendell Phillips-all of whom Higginson and the fournal community had held in high regard for decades. ${ }^{29}$ As Scott Giantvalley has shown, the essay on Whitman that Higginson included in the volume was a substantial revision of the harsh obituary notice that appeared in the New York Evening Post in 1892. Among other changes, Higginson removed all the implications that Whitman suffered from syphilis and added praise for "his personal picturesqueness" and "his services as an army nurse." Giantvalley notes possible reasons for Higginson's change of heart, such as "the mellowing of age" and the greater volume of positive press Whitman had been receiving (Giantvalley 1987, 22-23). The reconsiderations from his own suffrage community without doubt had a significant influence on Higginson as well.

In the coming years, as Whitman's reputation approached something close to celebrity status within the suffrage community and among those they hoped to influence, the Woman's fournal even began to appropriate specific portions of his poetry and prose. Although Whitman never came close to achieving the same status among suffragists as did Emerson or Margaret Fuller, his work celebrating both the advance of 
American democracy and women's unique strength came to be recognized and indeed utilized as a solid endorsement for women's capacity to enter fully into America's democratic promise. In 1900, the progressive mayor of Toledo, Samuel Milton Jones, in a two-column essay for the fournal, called for the women of America to awaken to their potential to improve public life through the vote and ultimately "to bring forth ... the perfected democracy, the ideal nation." Jones concluded the article with a sizable quotation from Whitman's Democratic Vistas, as follows: "Whitman, with prophetic vision, has told us that this is 'not the man's nation only, but the woman's nation, ... developed, raised to become the robust equals, workers, and it may be, even practical and political deciders with the men - greater than man, we may admit, with their divine maternity." 30 Although the passage may well provide evidence to those critics who fault Whitman for constructing women only as "Muscles and Wombs," such a construction did not preclude the fournal's ability to appropriate it for much more progressive purposes.

Through a number of other invocations, it became clear that the suffrage community tacitly came to accept that, since Whitman was the expansive poet of democracy, his legacy necessarily endorsed women's right to the vote. The conception held sway until the suffrage victory was finally achieved in 1919. In November of 1910, Catharine Wilde offered a review of Louise Downes's The New Democracy, which used Whitman to demonstrate that poetic vision was essential for the advance of woman suffrage. Wilde praised Downes's book for its endorsement of democracy, using "page after page of quotation from the Bible and Walt Whitman, of mystic suggestion and elaborate enunciation." 31 About six months later, poet, dramatist, and activist Josephine Preston Peabody sent a letter to the Fournal affirming that "equal suffrage will be [the] demonstration of true democracy" and expressed regret that she could not attend the New England Suffrage Festival in May. "[T] he month seems to me full of hope for man," she wrote, "beginning with the May Day celebrations all over the world, among the social thinkers, and ending (the $31^{\text {st }}$ ) with the birthday of Walt Whitman, poet of Democracy." 32 Whatever Whitman's ultimate conclusions were regarding women's equality, Peabody had pretty well drawn her own for the suffragists-Whitman and his verse served as a full-throated endorsement of American democracy and therefore of votes for women.

Perhaps the suffragists' fullest construction of Whitman as advocate of expanding circles of democratic reform and unity among suffrage activists came through his image of the pioneer-a construction most likely first set in motion by Gould's Gems from Walt Whitman. In 1909, selections from Whitman's "Pioneers! O Pioneers!" appeared in a letter from Beatrice Harraden, the British suffragist and novelist, which the fournal reprinted from the London Times. The letter delivered 
the impassioned argument that the common purpose in bringing the vote to women must put an end to the petty squabbling between the younger militant factions of the movement and those older and more conservative. Concluding with several rousing lines from "O Pioneers!" to remind women of their unity of purpose, Harraden wrote, "Walt Whitman's words should ring in our ears:"

O you young and elder daughters! O you mothers and you wives!

Never must you be divided, in our ranks you move united

We to-day's procession heading, we the route for travel clearing. . . . ${ }^{33}$

Harraden's appropriation of the passage for the suffrage cause shifts the reference point of "our ranks" from the general westward movement of "civilization" in Whitman's poem to the specific ranks of the suffragists - an image which would most certainly have resonated in the minds of readers with the column upon column of suffragist women marching through city streets both in Europe and America. Indeed, two years later, suffragist Harriet Stanton Blatch made explicit the connection between Whitman and the suffrage rally in her article "The Value of a Woman Suffrage Parade." She invoked Whitman and his assertion from "Song of Myself" that "logic and sermons never convince" to justify the suffragists' effort to generate emotive power with their rallies. ${ }^{34}$ To make the appropriation complete, Harraden dropped the first line of Whitman's stanza, "O you daughters of the West!," which was too place-specific for her purposes. Further, she added the last line from an earlier stanza in the poem. In its original context, again, the "We" refers to general westward expansion-primarily gendered masculine-along with a concomitant internal or spiritual expansion. In its new context, the line reinforces the image of women of all ages and stations of life joining the "procession" for woman suffrage- a conception Whitman never directly introduced in his poem. Nevertheless, as it was for Gould, Whitman's pioneer metaphor was exceptionally useful for women's concept of themselves as leaders of what was to them civilization's most important advancement.

As far as I can ascertain, women's appropriation of Whitman as fellow pioneer occurred once more in the pages of the fournal. Millicent Garret Fawcett, the English suffragist, Whitmanian, and president of the National Union of Woman Suffrage Societies, made the connection in a speech before the incoming class of the London School of Medicine for Women. The fournal reported that she encouraged the students to never forget the work of the pioneers who made their present careers possible, particularly Dr. Elizabeth Blackwell, Lucy Stone's sister-in-law. "The enthusiasm and genius of the pioneer had been sung by modern poets," she said, "particularly Walt Whitman and Rudyard Kipling." 35 
The fournal community's investment in Whitman's reputation was such that they were even willing to deflect negative press regarding the poet in order to maintain their association with him. In the same issue as the Fawcett article, a review appeared for Amanda Akin Stearns's Lady Nurse of Ward E, a memoir concerning the sacrifices of Civil War Nurses at Armory Square Hospital. Stearns's estimation of Whitman's service at the hospital was almost wholly negative and certainly a far cry from Gould's laudatory reminiscence. Unconcerned that the suffrage community had moved beyond its perception of Whitman as an expositor of Free Love, Stearns wrote:

Walt Whitman, visits our hospital almost daily. He took a fancy to my fever boy, and would watch with him sometimes half the night. He is a poet, and I believe has written some very queer books about "Free Love," etc. . . . When he stalks down the ward I feel the "pricking of my thumbs," and never speak to him, if not obliged to do so . . . With all his peculiar interest in our soldier boys he does not appeal to me. ${ }^{36}$

Rather than gratitude for Whitman's service, Stearns is almost afraid for the young soldiers to whom Whitman has become attached. Her antipathy, certainly, is nearly visceral. In assistant editor Catherine Wilde's review, however, all the deleterious references to Whitman's "peculiar" behavior were stripped out. Immediately after Wilde praises Lincoln's ministrations as reported by Stearns, Wilde writes, "And Walt Whitman came to watch by the dying boys, [and] sweet Mrs. Ripley from Concord, and others whose names are familiar." ${ }^{37}$ Not only does Wilde mischaracterize Whitman as an angel of mercy in Stearns's memoir, he is an angel of mercy in the same category as "sweet Mrs. Ripley," a nurse from Ward D of the hospital (Stearns, 150). Why Wilde indicates she is "familiar" and from Concord is unclear; perhaps she confused "Mrs. Ripley" with Transcendentalist icon Sophia Ripley, a mistake which would have helped seal the accord between Whitman and the Boston suffragists. At any rate, Wilde's review, no matter how inaccurate, served to reinforce Gould's earlier project of reclaiming Whitman as a Civil War hero among women for his hospital service.

In the final piece concerning Whitman in the Woman's fournal, from 1913, novelist and women's rights activist Mary Johnston argued, as Louise Downes did earlier, that artistic vision was essential for the advance of women's rights. Johnston was enormously successful at the century's turn; her novel To Have and to Hold was serialized in the Atlantic Monthly in 1899. When published in book form, it was the greatest commercial success between Uncle Tom's Cabin and Gone with the Wind. Her piece "The Woman Movement" invoked Whitman's "Song of the Broad-Axe" to demonstrate that "Artists are feminists." In a prose style strongly reminiscent of Whitman's own, she asked, "Why is the artist- 
whether poet or dramatist or prose writer, or painter or musician-why is the artist today so strongly interested in the Woman Movement?" The answer? "The artist applauds the Woman Movement because it is also the Artist's Movement, because it is a movement toward the world that the artist wishes to see, toward the world of harmony, and poesy, and beauty. The true artist loves strength and sweetness blended ... in one human frame. The true artist loves plasticity and freedom of the soul; he loves power and initiative; he never loved slavery." To bear out her point, Johnston quotes fourteen big-lunged lines from Whitman, including the following:

The great city is that which has the greatest man or woman [....]

Where women walk in public processions in the streets, the same as the men,

Where they enter the public assemblies and take places the same as the men [...]

Where the city of the healthiest of fathers stands;

Where the city of the best-bodied mothers stands;

There the great city stands. ${ }^{38}$

For Johnston, Whitman was a progressive feminist whose poetry had helped conceptualize new possibilities for women's full participation in civic affairs - possibilities which extended well beyond "the preeminence of maternal work," as Vivian Pollak termed it (92).

Whether or not present-day feminist critics reach consensus regarding Whitman's representations of gender, it seems clear that, at least in the national suffrage community represented and even formed by the Woman's fournal, Whitman was indeed an active advocate of votes for women. That consensus, of course, was nothing close to uniform over time. For a very long period, women and men registered the real concern that Whitman's unblinking representations of sex and the body would scare away much needed support from the staid northeastern middle classes. With the publication of Gems from Walt Whitman, however, it became possible and even beneficial for the suffragists to appropriate and manipulate a visionary yet fully clothed and duly chaste poetic persona. For the next twenty-five years, until the Nineteenth Amendment was passed and the fournal ceased publication, Whitman, the poet of democracy, served as an inspirational reminder that the promise of democracy had not yet been fulfilled.

The University of Texas of the Permian Basin 


\section{APPENDIX}

References to Walt Whitman in the Woman's fournal, 1870-1917

“Notes and News," Woman's fournal 6 (August 7, 1875), 253.

“Notes and News," Woman's fournal 6 (December 11, 1875), 397.

Squib, Woman's fournal 7 (April 29, 1876), 141.

Thomas Wentworth Higginson, “Unmanly Manhood,” Woman's fournal 13 (February 4,1882$), 33$.

“The Savage Ideal,” Woman's fournal 17 (July 3, 1886), 209.

Henry B. Blackwell, “Literary Notices,” Woman's fournal 21 (April 12, 1890), 115.

“Concerning Women,” Woman's fournal 21 (June 14, 1890), 185.

Ellen Battelle Dietrick, “One-Sided Criticism," Woman's fournal 23 (January 16, 1892), 18.

Theodore Ritter, "At the Manhattan Liberal Club," Woman's fournal 26 (March 23, 1895), 95.

Advertisement, “Whitman: A Study,” Woman's fournal 27 (December 12, 1896), 400.

“Literary Notices,” Woman's fournal 29 (September 3, 1898), 283.

“Gossip and Gleanings,” Woman's fournal 30 (October 21, 1899), 331.

Samuel Milton Jones, "Women and City Government," Woman's fournal 31 (July 21, 1900), 225.

“Gossip and Gleanings,” Woman's fournal 32 (April 6, 1901), 107.

Henry B. Blackwell, “In Memoriam,” Woman's fournal 37 (August 4, 1906), 123.

Beatrice Harraden, "Beatrice Harraden on Suffrage," Woman's fournal 40 (May 15, 1909), 78-79.

“Literary Notices," Woman's fournal 40 (July 3, 1909), 106.

"Pioneering," Woman's fournal 40 (December 18, 1909), 207.

C [atharine] W[ilde], “Literary Notices,” Woman's fournal 40 (December 18, 1909), 208.

C [atharine] W[ilde], “Literary Notices," Woman's fournal 41 (November 26, 1910), 215.

Josephine Preston Peabody, “Mrs. Mark's Letter," Woman's fournal 42 (June 3, 1911), 169.

Harriet Stanton Blatch, “The Value of a Woman Suffrage Parade," Woman's fournal 43 (May 4, 1912), 137.

Mary Johnston, “The Woman Movement," Woman's fournal 44 (March 15, 1913), 82-83. 


\section{NOTES}

I would like to thank the La Mancha Society at the University of Texas of the Permain Basin for granting me the Golden Windmill Award which allowed me to complete research for this essay, and Elizabeth Bilbrey for research assistance.

1 Horace Traubel, With Walt Whitman in Camden, 9 vols. (various publishers, 19051996), 2:331.

2 Joyce Warren, Fanny Fern: An Independent Woman (Piscataway: Rutgers University Press, 1992), 170. The D. H. Lawrence quotation is from his Studies in Classic American Literature (New York: Thomas Seltzer, 1923), 249. Those scholars who challenge Whitman's representations of women also include Vivian Pollak, who writes in her article "In Loftiest Spheres': Whitman's Visionary Feminism” that, although Whitman challenged "the nineteenth-century cult of domesticity and the allied doctrine of separate spheres, [he] also tended to reinscribe it." See Breaking Bounds: Whitman and American Cultural Studies, ed. Betsy Erkkila and Jay Grossman (Oxford: Oxford University Press, 1996), 108.

3 Sherry Ceniza, Walt Whitman and Nineteenth-Century Women Reformers (Tuscaloosa: University of Alabama Press, 1998), 35. Other prominent scholars favoring Whitman's representations of women include Betsy Erkkila, who writes that Whitman's poems "were invitations, beckoning women readers out of domestic confinement toward an open road of equality and comradeship with men." See Betsy Erkkila, Whitman the Political Poet (New York: Oxford University Press, 1996), 315.

4 No scholarship has yet appeared on the negotiation of Whitman's reputation in the suffrage community at large. Some, however, has appeared on individual women's influence on and reading of Whitman's work. Certainly the most comprehensive in this regard is Ceniza's Walt Whitman and Nineteenth-Century Women Reformers. See also Harold Aspiz, "An Early Feminist Tribute to Whitman," American Literature 51 (November 1979), 404-409 and "Walt Whitman, Feminist," Walt Whitman: Here and Now, ed. Joann P. Krieg (Westport, CT: Greenwood, 1985), 79-88; M. Jimmie Killingsworth, Whitman's Poetry of the Body: Sexuality, Politics, and the Text (Chapel Hill: University of North Carolina Press, 1989); David Reynolds, Walt Whitman's America: A Cultural Biography (New York: Knopf, 1995); Christina Davey, "Walt Whitman and the Quaker Woman," Walt Whitman Quarterly Review 16 (Summer 1998), 1-22; and Bryan Garman, "Heroic Spiritual Grandfather': Whitman, Sexuality, and the American Left, 1890-1940,” American Quarterly 52 (March 2000), 90-126.

5 Lucy Stone, with the help of abolitionists William Lloyd Garrison and Mary Livermore, organized the fournal after irreconcilable differences caused her to part ways with Susan B. Anthony and Elizabeth Cady Stanton. Stone and the affiliated American Woman Suffrage Association (AWSA) thought it best to work at state and municipal levels, while Stanton and Anthony, with their National Woman Suffrage Association (NWSA), fought the Republican administration for a constitutional amendment guaranteeing universal suffrage. The AWSA and the NWSA overcame their differences in 1890 and formed the National American Woman Suffrage Association (NAWSA). The fournal merged with Woman Voter and National Suffrage News in May 1917 to form the Woman Citizen. The title again changed to Woman's fournal in 1928 and ceased publication in 1931. As Susan Schultz Huxman has noted, the Woman's Fournal, despite its enormous influence, has received only scant scholarly attention. See Huxman, “The Woman's fournal, 1870-1890: The Torchbearer for Suffrage," A 
Voice of Their Own: The Woman Suffrage Press, 1840-1910, ed. Martha M. Solomon (Tuscaloosa: University of Alabama Press, 1991), 87. For other histories of the Woman's Fournal, see also E. Claire Jerry, "The Role of Newspapers in the Nineteenth-Century Woman's Movement," A Voice of Their Own, 17-29; Katharine Rodier, "Lucy Stone and The Woman's fournal," Blue Pencils and Hidden Hands: Women Editing Periodicals, 1830-1910, ed. Sharon M. Harris and Ellen Gruber Garvey (Boston: Northeastern University Press, 2004), 99-122; Lynne Masel-Walter, "A Burning Cloud by Day: The History and Content of the Woman [sic] Fournal," fournalism History 3 (Winter 1976-1977), 103-110; and Agnes E. Ryan, The Torch Bearer: A Look Forward and Back at the Woman's fournal, the Organ of the Woman's Movement (Boston: Woman's Journal and Suffrage News, 1916).

6 According to Reynolds, Whitman himself "shied away from what he saw as the free lovers' potentially disruptive effects on society" (223).

7 Eleanor Flexner, Century of Struggle: The Women's Rights Movement in the United States (Cambridge: Harvard University Press, 1975), 156-158.

8 Henry B. Blackwell, "Woman Suffrage and Free Love," Woman's fournal 5 (September 12, 1874), 294.

9 M. G. Charlton, “A False Accusation," Woman's fournal 7 (August 5, 1876), 254-255.

10 Henry B. Blackwell, "Who Were the Early Suffragists?" Woman's Fournal 23 (July 23, 1892), 236-237. See my article "Publishing the Cause of Suffrage: The Woman's Fournal's Appropriation of Ralph Waldo Emerson in Postbellum America" (New England Quarterly 79 [December 2006], 578-608) for more on the fournal's manipulation of Emerson's name and writings to produce an endorsement for suffrage.

11 "Notes and News," Woman's fournal 6 (August 7, 1875), 253. The article referred to in the Springfield Republican is "Walt Whitman. His Life, His Poetry, Himself," published on July 23, 1875. The piece is cited in Scott Giantvalley's Walt Whitman, 1838-1939, A Reference Guide (Boston: G. K. Hall, 1981), 37, and it is reprinted in Kenneth Walter Cameron's The New England Writers and the Press (Hartford: Transcendental Books, 1980), 156-159. Edwin Haviland Miller writes, "though the article was signed with the initials J.M.S. (James Matlock Scovel), Burroughs observed on July 27, 1875: 'It is an admirable piece of writing (of course I see your hand) \& contains some of the best things about you that have yet been in print"' (Corr 2, 337).

12 Thomas Wentworth Higginson, "Walt Whitman" New York Evening Post (March 28, 1892), 1:1-3. See Scott Giantvalley's “'Strict, Straight Notions of Literary Propriety': Thomas Wentworth Higginson's Gradual Unbending to Walt Whitman" (Walt Whitman Quarterly Review 4 [Spring 1987], 17-27) for a complete discussion of the obituary.

13 "Notes and News," Woman's fournal 6 (December 11, 1875), 397. The author of the article is quoting either from Joaquin Miller's Whitman tribute in the New York Tribune, which, according to Giantvalley's Walt Whitman, 1838-1939, A Reference Guide (37), is unlocated, or from the anonymous essay "Walt Whitman" which quotes extensively from Miller and appeared in Cope's Tobacco Plant (1 [December 1875], 834) shortly after the Tribune piece (227). "Walt Whitman" may be readily accessed in James Thomson's edited volume Walt Whitman, the Man and the Poet (London: self published, 1910), 40-42. 
14 Thomas Wentworth Higginson, "Unmanly Manhood," Woman's fournal 13 (February 4, 1882), 33.

15 The most comprehensive consideration of the Higginson / Whitman relationship is Ed Folsom's essay “Transcendental Poetics: Emerson, Higginson, and the Rise of Whitman and Dickinson" (The Oxford Handbook to Transcendentalism, ed. Joel Myerson, Sandra Petrulionis, and Laura Walls [Oxford: Oxford University Press, 2010], 263-290), which argues that Higginson disliked Whitman and his bold sensual poetry because the former was a second-generation Transcendentalist deeply aligned with Emerson's poetic sensibilities. My thanks to Professor Folsom for allowing me to see the essay in manuscript. Scott Giantvalley's “'Strict, Straight Notions of Literary Propriety': Thomas Wentworth Higginson's Gradual Unbending to Walt Whitman" takes Higginson at his own word and demonstrates how his dislike of Whitman was based on his treatment of sex, his unwillingness to fight in the Civil War, and his disregard for poetic convention. Robert K. Nelson and Kenneth M. Price's "Debating Manliness: Thomas Wentworth Higginson, William Sloane Kennedy, and the Question of Whitman" (American Literature 73 [September 2001], 497-524) argues that Higginson's antipathy was a New England Brahmin's class-based response to a New York working class "rowdy."

16 See for example Nelson and Price, 501.

17 “The Savage Ideal,” Woman's fournal 17 (July 3, 1886), 209.

18 The quotation is from Sidney Lanier's The English Novel and the Principle of Its Development (New York: Charles Scribner's Sons, 1883), 53-55. Only five years earlier, Lanier had sent a letter asking Whitman to count him "among [his] most earnest lovers." See "Poems and Minor Pieces," In Re Walt Whitman, ed. Horace Traubel, Maurice Bucke, and Thomas Harned (Philadelphia: David McKay, 1893), 392.

19 See Nelson and Price for more on New England Brahmin fears of working class constructions of masculinity. As they report (519), Higginson's article "Women and Men: The Victory of the Weak" appeared in Harper's Bazar (March 26, 1887), 214.

20 Walt Whitman, Gems from Walt Whitman, ed. Elizabeth Porter Gould (Philadelphia: David McKay, 1889).

21 Ed Folsom, "Leaves of Grass, Funior: Whitman's Compromise with Discriminating Tastes," American Literature 63 (December 1991), 648.

22 Edward Whitley, "Elizabeth Porter Gould, Author of Leaves of Grass: Gender, Editing, and the Nineteenth-Century Literary Marketplace," English Language History 75 (Summer 2008), 483.

23 See Henry B. Blackwell's “In Memoriam” (Woman's fournal 37 [August 4, 1906], 123) and "Women's Clubs and Club Women" (Woman's fournal 30 [December 2, 1899], 384).

24 Henry B. Blackwell, “Literary Notices,” Woman's fournal 21 (April 12, 1890), 115.

25 “Concerning Women," Woman's fournal 21 (June 14, 1890), 185. Ruth L. Bohan, Looking into Walt Whitman: American Art, 1850-1920 (University Park: Pennsylvania State University Press, 2006), 87-89. According to Bohan, Whitman displayed Wheeler's painting for a time in his Mickle Street home. 
26 Theodore Ritter, "At the Manhattan Liberal Club," Woman's fournal 26 (March 23, 1895), 95.

27 Advertisement, "Whitman: A Study," Woman's fournal 27 (December 12, 1896), 400 .

28 "Literary Notices," Woman's fournal 29 (September 3, 1898), 283. The review was almost certainly written by Henry B. Blackwell or Alice Stone Blackwell. The complete bibliographic record for this edition is Complete Prose Works (Boston: Small, Maynard, 1898).

29 “Gossip and Gleanings," Woman's fournal 30 (October 21, 1899), 331.

30 Samuel Milton Jones, "Women and City Government," Woman's fournal 31 (July 21, 1900), 225.

31 C [atharine] W[ilde], "Literary Notices," Woman's fournal 41 (November 26, 1910), 215. Louise Downes, The New Democracy (Boston: Sherman, French \& Co., 1910).

32 Josephine Preston Peabody, “Mrs. Mark's Letter," Woman's fournal 42 (June 3, 1911), 169.

33 Beatrice Harraden, "Beatrice Harraden on Suffrage," Woman's fournal 40 (May 15, 1909), 78-79.

34 Harriet Stanton Blatch, "The Value of a Woman Suffrage Parade," Woman's fournal 43 (May 4, 1912), 137.

35 "Pioneering," Woman's fournal 40 (December 18, 1909), 207. Additionally, Fawcett, according to Giantvalley's Walt Whitman, 1838-1939: A Reference Guide, was a known Whitmanian.

36 Amanda Akin Stearns, Lady Nurse of Ward E (New York: Baker and Taylor, 1909), 56-57. See also Martin G. Murray, "Traveling with the Wounded: Walt Whitman and Washington's Civil War Hospitals," Washington History 8 (Fall/Winter 1996-1997), 58-73; 92-93.

37 C [atharine] W[ilde], "Literary Notices," Woman's fournal 40 (December 18, 1909), 208.

38 Mary Johnston, “The Woman Movement," Woman's fournal 44 (March 15, 1913), 82-83. 